\title{
DETERMINAÇÃO DE ÁREAS PARA INSTALAÇÃO DE INSTRUMENTOS HIDROMETEOROLÓGICOS EM MICROBACIAS POR MEIO DO SIG
}

\author{
AREAS DETERMINATION FOR HYDROMETEOROLOGICAL INSTRUMENTS INSTALATION IN \\ MICROBASINS USING GIS
}

\author{
Solivan ALTOÉ, Adilson Marcio COELHO \\ Instituto Federal de Educação, Ciência e Tecnologia do Espírito Santo (IFES) - Campus Nova Venécia. Nova Venécia, ES. \\ Emails: solivanaltoe@gmail.com; adilmarcoe@ifes.edu.br
}

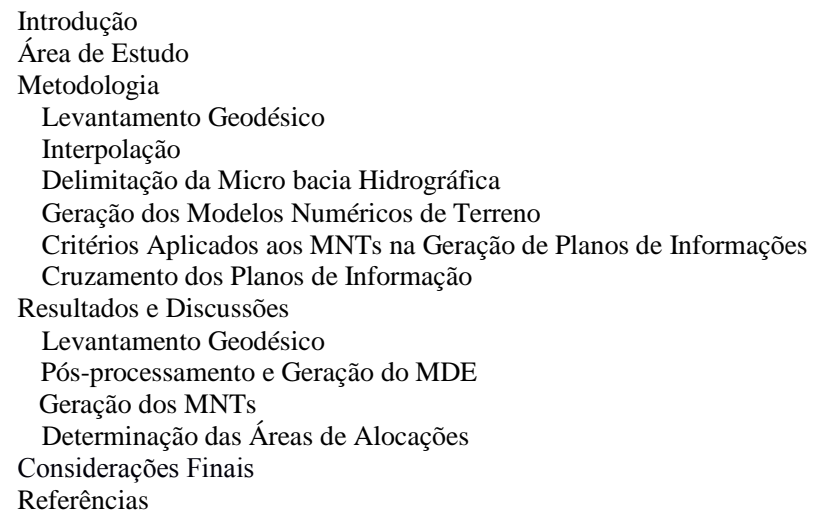

RESUMO - Uma forma de se estudar microbacias hidrográficas se dá a partir de dados coletados por instrumentos hidrometeorológicos, mas, o que se percebe é que há poucos estudos no Brasil sobre metodologias de alocação desses instrumentos. Logo, o propósito dessa pesquisa foi usar o Sistema de Informações Geográficas (SIG) ArcGIS ${ }^{\circledR} 10.5$ como ferramenta na determinação de regiões propícias à alocação de quatro instrumentos: estação fluviométrica, estação hidrometeorológica, tensiômetro e piezômetro, a partir dos cruzamentos de planos de informações gerados dos Modelos Numéricos de Terreno (MNTs) de elevação, declividade, orientação e curvatura das vertentes. A área estudada foi a microbacia da cabeceira do Córrego Dezoito no município de São Mateus, Espírito Santo. O Modelo Digital de Elevação (MDE) necessário para a geração dos MNTs foi gerado por meio do método de interpolação top to raster, e as cotas foram obtidas por meio de levantamento geodésico da bacia no modo stop and go. Os resultados foram mapas das regiões propícias à instalação dos instrumentos conforme os cruzamentos dos parâmetros elevação, declividade, orientação e curvatura. O uso do SIG foi eficiente e tornou objetiva a determinação das regiões de alocação dos instrumentos.

Palavras-chave: Microbacia hidrográfica. SIG. Geoprocessamento. Alocação de instrumentos. Instrumentos hidrometeorológicos.

\begin{abstract}
One way to study a microbasin is collect data by hydrometeorological instruments. However, there are few studies in Brazil about allocation methodologies for these instruments. Therefore, the purpose of this research had been use Geographic Information System (GIS) ArcGIS ${ }^{\circledR} 10.5$ as a tool to determine suitable regions to allocate four instruments: fluviometric station, hydrometeorological station, tensiometer and piezometer using information plans intersections generated from Numerical Terrain Models (NTMs) of elevation, slope, orientation and slopes curvature. The studied area had been the Córrego Dezoito microbasin headwater, at São Mateus county, State of Espírito Santo. The Digital Elevation Model (DEM) required for the NTMs generation had been created by top to raster interpolation method and the dimensions basin were obtained by geodetic survey in stop and go mode. This research have got suitable regions maps for each instrument installation according to the crossings parameters elevation, slope, orientation and curvature. The use of GIS was efficient and made objective the instruments allocation.
\end{abstract}

Keywords: Microbasin. GIS. Geoprocessing. Instruments Allocation. Hydrometeorological Instrumentation.

\section{INTRODUÇÃO}

Uma bacia hidrográfica é entendida como uma área da superfície terrestre drenada por um canal principal e seus afluentes, e representa, portanto, a área de captação que faz convergir o escoamento superficial para um único ponto de saída, o exutório (Novo, 2008).

Esse conceito permite que se tenham bacias formadas por um único canal e outras formadas por vários canais, de modo que se tenha, por consequência, a bacia de uma nascente e a bacia de um grande rio. Quando se trata de nascentes ou cabeceiras de córregos ou riachos, a dimensão deve ser de até 10.000 ha (Assad et al., 1998), e nesse caso, a área de captação é chamada de microbacia hidrográfica, pequena bacia ou até mesmo de bacia experimental quando ela é estudada (BRASIL, 1987).

Pela legislação brasileira, a bacia hidrográfica é a unidade territorial para gerenciamento dos recursos hídricos (BRASIL, 1997), o que significa que é a partir de uma bacia hidrográfica que toda ação de gerenciamento dos recursos hídricos deve ser planejada, implementada, monitorada, avaliada e corrigida.

A partir disso, fica entendido que o estudo de bacias hidrográficas visará não só investigar processos hidrológicos, mas também aplicar o 
conhecimento adquirido em ações políticas de planejamento dos múltiplos usos dos recursos hídricos sob uma perspectiva sustentável. Além disso, dado que cerca de $80 \%$ das nascentes dos rios que passam pelas regiões mais habitadas do país estão em propriedades agropecuárias (Valente, 2011), torna-se muito importante o estudo delas em propriedades rurais.

A instalação e uso de instrumentos em bacias é denominada instrumentação de bacia hidrográfica e as bacias instrumentadas tornamse bacias experimentais (Mota et al., 2016). Em estudos de bacias, o uso de instrumentos de monitoramento e medição direta de dados hidrometeorológicos sempre foram importantes, como é o caso do vertedor, que mede parâmetros do fluxo do canal.

Adicionalmente, nos dias atuais as pesquisas têm utilizado cada vez mais os Sistemas de Informações Geográficas (SIGs), o que tem tornado os estudos mais acessíveis, automatizados e rápidos.

A atual tecnologia permite criar modelos numéricos de terreno (MNTs), como o modelo digital de elevação (MDE). Este, por sua vez, permite aos usuários ter qualquer bacia delimitada automaticamente por algoritmos, além de possibilitar cálculos de índices morfométricos e análises numéricas do terreno
(Vargas et al., 2011).

Entretanto, existe uma carência de pesquisas sobre instrumentação de bacias. Mota et al. (2016) percebeu uma falta de metodologia para alocação de instrumentos após analisar várias publicações científicas sobre trabalhos em pequenas bacias experimentais.

Em relação ao uso de SIG, há muitos trabalhos realizados com MDEs, porém sempre tratando da caracterização da bacia para fins diversos, mas não para instrumentação, como se vê em trabalhos como os de Marques et al. (2011) e Cecílio et al. (2013) que tratam de delimitação de bacias, e os de Santos et al. (2012) e Passarella et al. (2016) que tratam sobre geomorfologia de bacias.

A alocação é fundamental para a eficiência da coleta de dados e deve-se buscar maior objetividade nesse processo. Portanto, o objetivo deste trabalho foi processar, analisar e obter informações geográficas por meio de SIG a fim de determinar áreas propícias à instalação de quatro instrumentos hidrometeorológicos: estação fluviométrica, estação meteorológica, tensiômetro e piezômetro em uma pequena bacia hidrográfica.

O método pretendeu tornar objetiva a determinação das possíveis áreas, orientando o processo decisório de alocação dos instrumentos.

\section{ÁREA DE ESTUDO}

A área de estudo é a microbacia da cabeceira do Córrego Dezoito, localizada na latitude $18^{\circ} 48^{\prime} 22^{\prime \prime}$ 'S e longitude $40^{\circ} 16^{\prime} 48^{\prime \prime}$ 'O, pertencente ao município de São Mateus, nordeste do estado do Espírito Santo, e fica a aproximadamente $58 \mathrm{~km}$ da sede municipal. A bacia está inserida em ambiente geológico formado de sedimentos terciários e seu relevo apresenta ondulações caracterizadas pela transição do relevo de tabuleiros do litoral para relevo cristalino précambriano presente no interior do estado (Panoso et al. 1978).

O clima da região é seco com temperatura média de $25,39^{\circ} \mathrm{C}$ e pluviosidade entre 1000 a $1100 \mathrm{~mm}$ anual (Espírito Santo/Instituto Jones Dos Santos Neves, 2011). O uso do solo da bacia se dá com pastagem, lavoura e eucalipto, não havendo nenhum fragmento de floresta nativa. A figura 1 mostra a microbacia e sua localização.

O Córrego Dezoito deságua no Rio Barra Seca, no município de Jaguaré, ES, já na divisa com o município de Sooretama. A foz se dá próximo à Reserva Biológica de Sooretama. Ambas as bacias se inserem na bacia do Rio Doce, e essa por sua vez faz parte da região hidrográfica Atlântico Sudeste, na classificação da Agência Nacional de Águas (ANA). A figura 2 mostra a localização da bacia de estudo dentro da bacia do Córrego Dezoito.

Os canais de drenagem que formam a bacia do Córrego Dezoito cortam propriedades rurais, na maioria pequenas propriedades, constituindo a única fonte de água superficial para a irrigação das lavouras. Por ser a região uma grande produtora de café conilon e pimenta do reino e essas atividades serem a base da economia local, a bacia possui tamanha importância para o desenvolvimento da região. Além disso, ela também é responsável por abastecer a represa do Jundiá que fornece água para o abastecimento público da cidade de Jaguaré, o que mostra outra grande importância da bacia para a região. 


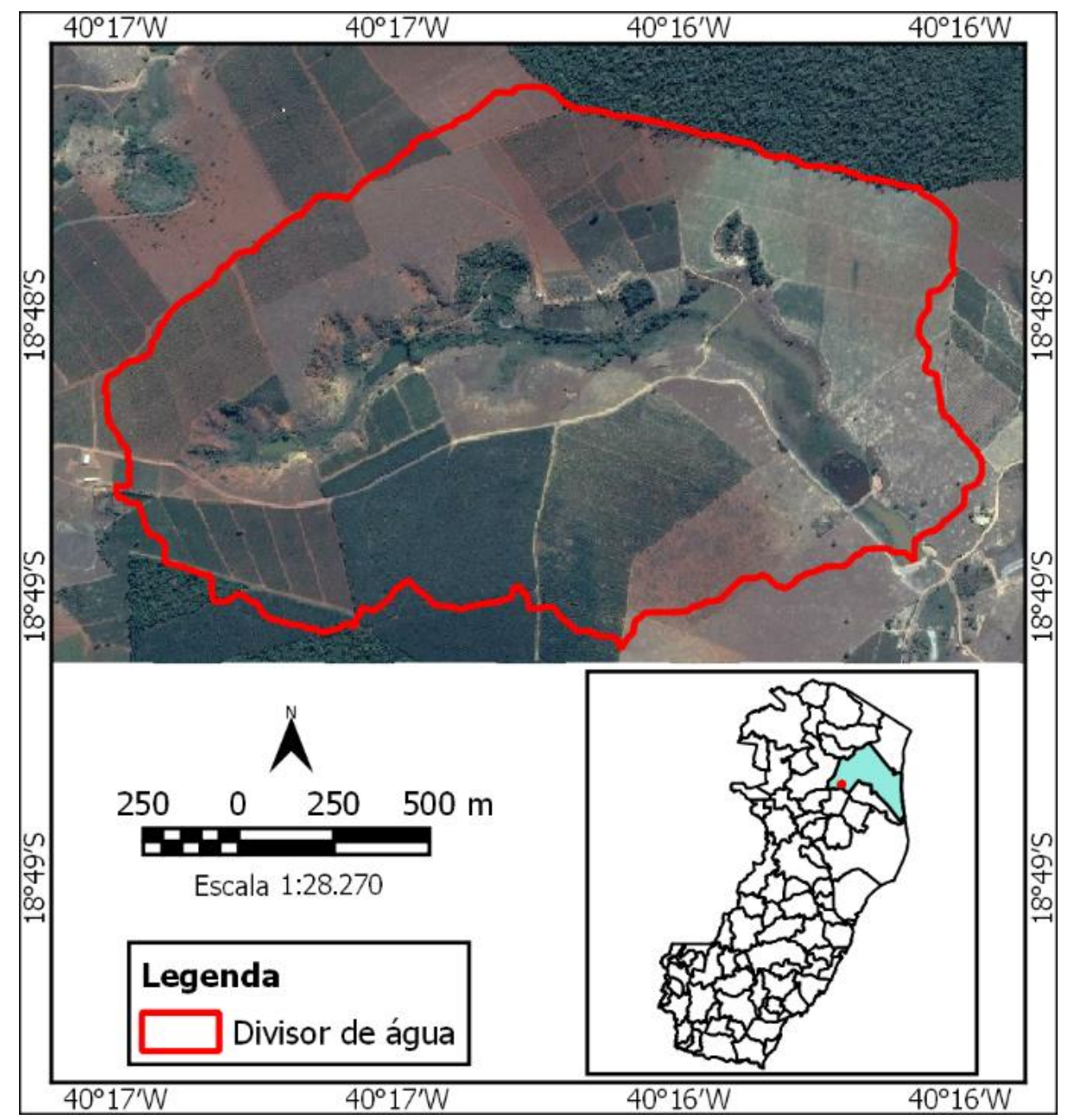

Figura 1 - Imagem da bacia do Córrego Dezoito e sua localização no estado do Espírito Santo.

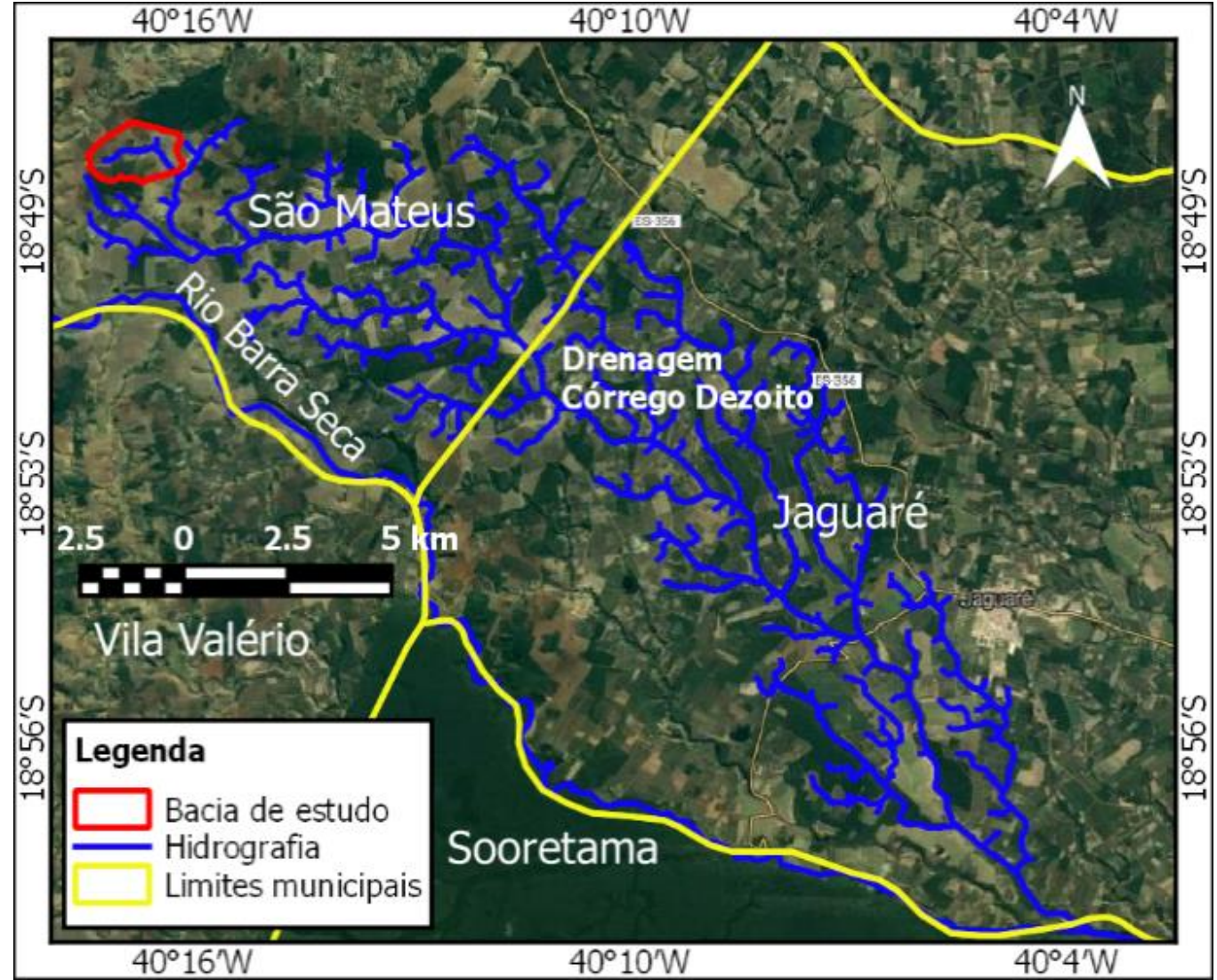

Figura 2 - Área e localização da bacia de estudo na bacia do Córrego Dezoito. 


\section{METODOLOGIA}

A metodologia empregada na realização deste trabalho segue o esquema da figura 3 .

\section{Levantamento Geodésico}

Para a aquisição de dados altimétricos da bacia, foi empregado o levantamento geodésico em vez de levantamento topográfico ou mesmo das imagens da Shuttle Radar Topograph Mission (SRTM). Essa opção foi feita por vários motivos: no levantamento geodésico, em que se usam receptores GNSS, não precisa de intervisibilidade entre pontos e basta um operador por receptor, diferindo dos equipamentos topográficos, como a estação total, em que são necessários dois operadores por equipamento e intervisibilidade entre os pontos. Além disso, a altimetria obtida é muito mais precisa quando comparada com a altimetria das imagens da SRTM pelo fato dessas últimas estarem disponíveis com resolução espacial de $30 \mathrm{~m}$ e apresentarem cotas menos confiáveis devido às limitações do uso de radar no imageamento da superfície terrestre.

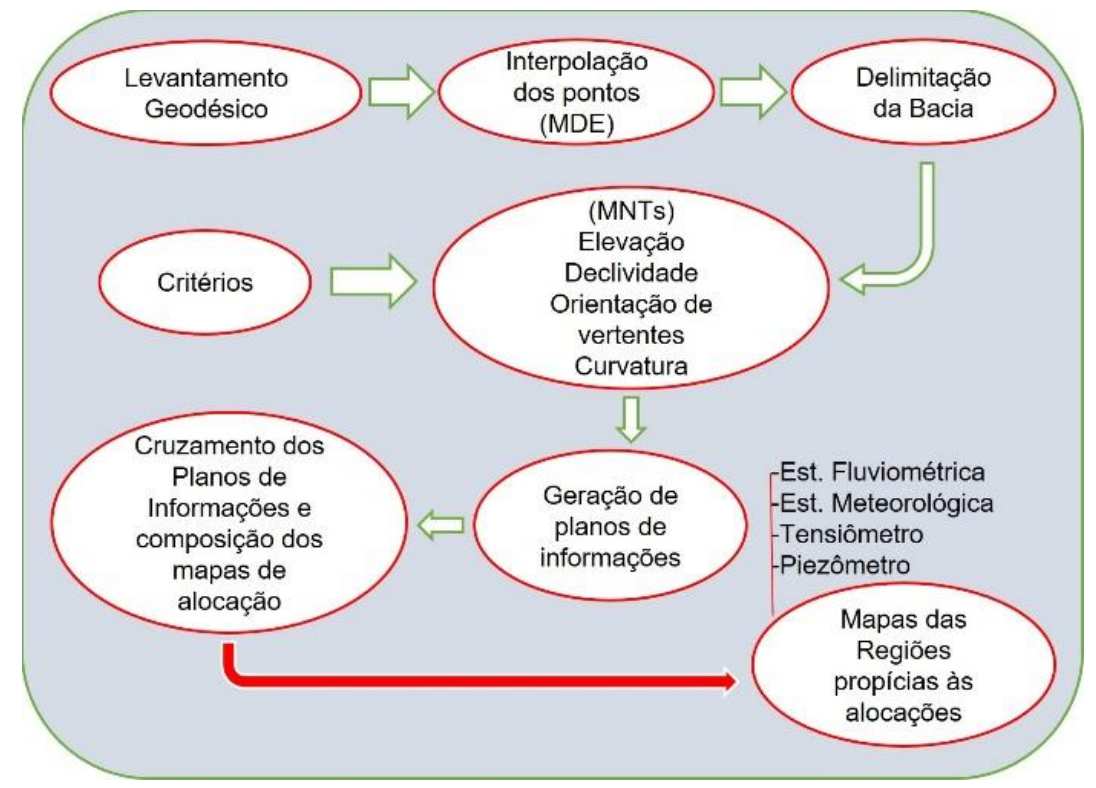

Figura 3 - Diagrama da metodologia de trabalho.

O levantamento geodésico foi feito por meio de três receptores do Sistema de Navegação Global por Satélites (em inglês, GNSS), sendo um par de receptores GPS (Sistema de Posicionamento Global - sistema estadunidense) que recebe a portadora $\mathrm{L} 1 \mathrm{e}$ um receptor dos sistemas GPS, GLONASS e SBAS que recebe a portadora L1 e L2 (GLONASS: Sistema de Navegação Global por Satélites - sistema russo; SBAS: Sistema de Aumento por Satélite - visa corrigir erros do posicionamento pelo GPS). O modo de levantamento foi o posicionamento relativo stop and go, no qual o receptor L1/L2, por ter maior acurácia, ficou como base operando em modo estático e o par de receptores L1 foi operado como rover no modo stop and go. A obtenção das coordenadas da base se deu por pós-processamento no PPP (Posicionamento por Ponto Preciso) por meio do aplicativo on-line IBGE-PPP. As linhas de base dos rovers foram pós-processadas através do programa GNSS Solutions.

\section{Interpolação}

A partir dessa etapa todas as atividades desta pesquisa foram feitas em ambiente de SIG. Optou-se pelo SIG ArcGIS ${ }^{\circledR}$, versão 10.5 da Environmental Systems Research Institute, Inc. (ESRI) por sua larga faixa de opções em processamento de informações geográficas. Para obter o MDE da área de estudo, foi utilizado o método de interpolação topo to raster disponível na extensão $\operatorname{ArcMAP}^{\mathrm{TM}}$ do ArcGIS para interpolar os pontos cotados obtidos do levantamento geodésico. Esse método foi usado por apresentar resultado superior entre os demais métodos de interpolação em MDEs, como concluíram os trabalhos de Guedes et al. (2011) e Schlosser et al. (2012) quando avaliaram a precisão de diferentes métodos de interpolação como ordinary krigging, natural neighbors, inverse distance weighted (IDW) e topo to raster na aplicação em MDE, usando comparações a partir de análises estatísticas com pontos de controle e validação cruzada. 


\section{Delimitação da Microbacia Hidrográfica}

A bacia foi delimitada de forma supervisionada por meio das ferramentas de hidrologia da caixa de ferramentas do ArcMAP $^{\mathrm{TM}}$. A figura 4 mostra fluxograma descritivo do processo utilizado, passo a passo.

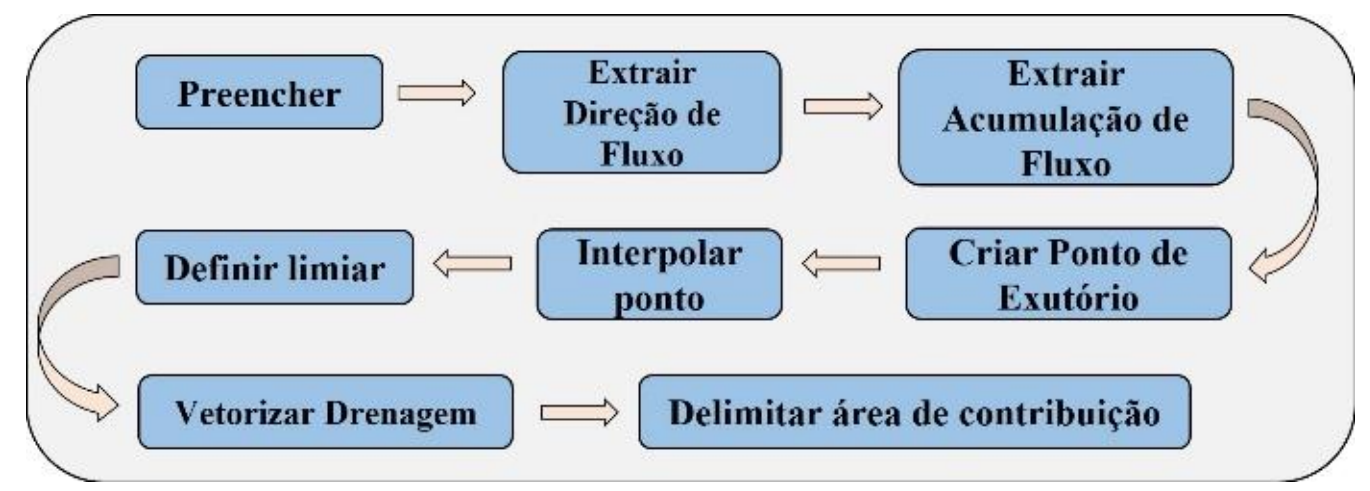

Figura 4 - Processo de delimitação supervisionada de bacias hidrográficas no ArcMAP ${ }^{\mathrm{TM}}$, caixa de ferramentas hidrologia.

Inicialmente, foi gerado um Modelo Digital de Elevação Hidrologicamente Consistente (MDEHC), após aplicar o comando fill e flow direction. O primeiro, preenche as depressões espúrias; o segundo, determina as direções de fluxos sobre toda a área comparando a cota de cada pixel com as cotas dos 8 pixels ao seu redor, determinando a direção da inclinação de cada pixel segundo a direção da célula de menor altitude da vizinhança, para que a água escoe nessa direção.

Depois de gerado o MDEHC, foi feita a análise de acúmulo de fluxo, isto é, a determinação de canais de drenagem para onde convergem as direções dos fluxos, com o comando flow accumulation. Em seguida foi inserido um shape do tipo ponto no local do exutório da bacia a fim de determinar toda a área de contribuição responsável por direcionar todo o escoamento para esse ponto, sendo que depois foi interpolado pra receber um valor de cota de elevação. Depois disso, foi inserido um valor de limiar de 22000 para se chegar à rede drenagem que coincide com drenagem real da bacia usando o comando con.

Esse limiar significa a quantidade de células a serem analisadas pelo algoritmo durante a determinação da rede de drenagem sobre o terreno - quanto maior, menor a quantidade de canais criados. Após o limiar, fez-se a vetorização dessa drenagem através do comando stream to feature. Por fim, utilizando o comando watershed determinou-se a área de contribuição a partir do exutório inserido como ponto shape. O resultado após esse último algoritmo representa a área $\mathrm{da}$ bacia delimitada.

\section{Geração dos Modelos Numéricos de Terreno}

Neste trabalho, optou-se em definir os critérios de alocação dos instrumentos a partir de 4 atributos fisiográficos da bacia: elevação, declividade, orientação das vertentes e curvatura, como apresentados por Nascimento et al. (2012) e Barros et al. (2015) em seus estudos de caracterização morfométrica de terrenos de bacia hidrográfica. Para a extração dos atributos, foi necessária a geração de modelos numéricos a partir do MDE, atividade feita no ArcMAP.

\section{Critérios Aplicados aos MNTs na Geração de Planos de Informações}

Após a geração dos MNTs, tinham-se 4 modelos numéricos do terreno da bacia: declividade, orientação, curvatura e elevação que, em seguida, foram tratados por critérios determinados a partir da classificação dos atributos fisiográficos em alto, intermediário, baixo, côncavo, convexo, norte, sul, leste e oste, e enquadrados em valores numéricos definidos em função dos valores mínimo e máximo de cada MNT, no qual se chegou a planos de informações.

A tabela 1 apresenta a definição dos critérios para cada atributo fisiográfico.Para determinar o valor numérico dos critérios de elevação e declividade, baseou-se nos valores máximo e mínimo desses atributos após a geração dos respectivos MNTs.

A cota máxima e mínima da bacia foi, respectivamente, $205 \mathrm{~m}$ e $91 \mathrm{~m}$. A partir desses valores, definiu-se que de $91 \mathrm{~m}$ a $116 \mathrm{~m}$ classificava-se como baixa elevação; entre $116 \mathrm{~m}$ a $180 \mathrm{~m}$, como elevação intermediária; acima de $180 \mathrm{~m}$ até $205 \mathrm{~m}$, de elevação alta. Para 
a declividade, cujos valores máximo e mínimo foram, respectivamente, $0^{\circ}$ e $63^{\circ}$, estabeleceuse que de $0^{\circ}$ a $10^{\circ}$ fosse baixa declividade; entre $10^{\circ}$ e $30^{\circ}$, declividade intermediária; acima de $30^{\circ}$ até $63^{\circ}$, alta declividade. Para a orientação de vertentes, consideraram-se apenas as 4 direções cardeais, definidas em uma faixa de $10^{\circ}$ cada uma, conforme a tabela 1. Para a curvatura, utilizou-se a definição dada pelo próprio programa em que curvaturas menores que $0 \%$ são definidos como côncavas e curvaturas maiores que $0 \% \mathrm{~m}$ são convexas.

Tabela 1 - Definição dos critérios.

\begin{tabular}{l|l|l}
\hline \multirow{4}{*}{ Atributo } & Critério & Valor \\
\hline \multirow{4}{*}{ Declividação } & Alta & $>=180 \mathrm{~m}$ \\
\cline { 2 - 3 } & Intermediária & $116 \mathrm{~m}<$ elev $<180 \mathrm{~m}$ \\
\cline { 2 - 3 } & Baixa & $<=116 \mathrm{~m}$ \\
\hline \multirow{4}{*}{ Orientação } & Alta & $>=30^{\circ}$ \\
\cline { 2 - 3 } & Intermediária & $10^{\circ}<$ decliv $<30^{\circ}$ \\
\cline { 2 - 3 } & Baixa & $<=10^{\circ}$ \\
\hline \multirow{2}{*}{ Curvatura } & Norte & $355-5^{\circ}$ \\
\cline { 2 - 3 } & Sul & $175-185^{\circ}$ \\
\cline { 2 - 3 } & Leste & $85-95^{\circ}$ \\
\cline { 2 - 3 } & Oeste & $265-275^{\circ}$ \\
\hline & Côncava & $<0^{\circ} / \mathrm{m}$ \\
\cline { 2 - 3 } & Convexa & $>0^{\circ} / \mathrm{m}$ \\
\hline
\end{tabular}

Pelo fato de que não há trabalhos publicados que investiguem os critérios de alocação e não faz parte do objetivo desta pesquisa investigálos, o uso dos critérios apresentados na tabela 1 se deu apenas para testar a aplicação de SIG no processo de alocação dos instrumentos.

Para a determinação dos critérios a serem usados na alocação de cada instrumento, utilizou-se um método de escolha discreta de aceitar/rejeitar, que contou com o auxílio das tabelas 2 a 5 , nas quais a última coluna traz 0 ou 1 , sendo o número 0 para critério rejeitado e o número 1 para critério aceito.

Estação fluviométrica: A tabela abaixo mostra que na determinação das áreas propícias à instalação da estação fluviométrica foram utilizados os critérios: elevação baixa, declividade alta, curvatura convexa.

Sabe-se que a estação fluviométrica deve ser instalada obrigatoriamente no canal, no caso desse trabalho o córrego, e no exutório da bacia. Mas os critérios utilizados pretenderam encontrar no canal, desde a nascente ao exutório, seções transversais preferencialmente declivosas, estreitas e de curvatura convexa para facilitar a construção da barragem necessária à estação. Os critérios também visaram encontrar seções do canal à jusante propícias à instalação para a hipótese de se instalar mais de uma estação.

Tabela 2 - Critérios para alocação da estação fluviométrica.

\begin{tabular}{l|l|l|c}
\hline Atributo & Critério & Valor & Decisão \\
\hline \multirow{4}{*}{ Elevação } & Alta & $>=180 \mathrm{~m}$ & 0 \\
\cline { 2 - 4 } & Intermediária & $116 \mathrm{~m}<\mathrm{elev}<180 \mathrm{~m}$ & 0 \\
\cline { 2 - 4 } & Baixa & $<=116 \mathrm{~m}$ & 1 \\
\hline \multirow{4}{*}{ Oeclividade } & Alta & $>=30^{\circ}$ & 1 \\
\cline { 2 - 4 } & Intermediária & $10^{\circ}<$ decliv $<30^{\circ}$ & 0 \\
\cline { 2 - 4 } & Baixa & $<=10^{\circ}$ & 0 \\
\hline \multirow{4}{*}{ Curvatura } & Norte & $355-5^{\circ}$ & 0 \\
\cline { 2 - 4 } & Sul & $175-185^{\circ}$ & 0 \\
\cline { 2 - 4 } & Leste & $85-95^{\circ}$ & 0 \\
\cline { 2 - 4 } & Oeste & $265-275^{\circ}$ & 1 \\
\hline
\end{tabular}


Estação meteorológica: No caso da estação meteorológica, a tabela abaixo mostra que a determinação das áreas propícias à instalação utilizou os critérios elevação alta - intermediária - baixa; declividade baixa; e orientação de vertentes norte/sul/leste/oeste.

A elevação é importante na alocação da estação devido à variabilidade espacial da chuva e à variabilidade altimétrica de pressão atmosférica e temperatura do ar; a importância da declividade baixa na alocação da estação se dá por favorecer a instalação, a manutenção, o acesso ao local, além de reduzir a ação dos processos erosivos no local da instalação, o que comprometeria o bom funcionamento do instrumento; a orientação das vertentes é importante pelo fato de que ela influencia na iluminação solar sobre a superfície.

Tabela 3 - Critérios para alocação das estações meteorológicas.

\begin{tabular}{l|l|l|c}
\hline Atributo & Critério & Valor & Decisão \\
\hline \multirow{4}{*}{ Elevação } & Alta & $>=180 \mathrm{~m}$ & 1 \\
\cline { 2 - 4 } & Intermediária & $116 \mathrm{~m}<$ elev $<180 \mathrm{~m}$ & 1 \\
\cline { 2 - 4 } & Baixa & $<=116 \mathrm{~m}$ & 1 \\
\hline \multirow{4}{*}{ Declividade } & Alta & $>=30^{\circ}$ & 0 \\
\cline { 2 - 4 } & Intermediária & $10^{\circ}<$ decliv $<30^{\circ}$ & 0 \\
\cline { 2 - 4 } & Baixa & $<=10^{\circ}$ & 1 \\
\hline \multirow{4}{*}{ Curvatuação } & Norte & $355-5^{\circ}$ & 1 \\
\cline { 2 - 4 } & Sul & $175-185^{\circ}$ & 1 \\
\cline { 2 - 4 } & Leste & $85-95^{\circ}$ & 0 \\
\cline { 2 - 4 } & Oeste & $265-275^{\circ}$ & 0 \\
\hline & Côncava & $<0^{\circ} / \mathrm{m}$ & 1 \\
\cline { 2 - 4 } & Convexa & $>0 \% \mathrm{~m}$ & \\
\hline
\end{tabular}

Tensiômetro: A utilidade do tensiômetro advém da necessidade de se monitorar a dinâmica da umidade na superfície do terreno, resultado da infiltração da água da chuva e da evapotranspiração. Em associação à estação meteorológica, ajuda a monitorar a dinâmica da água na interface solo/atmosfera.

A forma da superfície influencia diretamente na dinâmica de infiltração da água no solo devido a seus atributos elevação, declividade, orientação e curvatura. A elevação, associada à gravidade e iluminação solar, vai influenciar na movimentação umidade e na evapotranspiração; a orientação das vertentes, associada à direção do movimento do sol e predominância dos ventos, influenciam na evapotranspiração; a curvatura, associada à velocidade do escoamento, influencia na infiltração. Normalmente, pela ação erosiva, os topos dos morros ganham a forma de curvatura convexa enquanto que as bases ficam côncavas. Por isso, optou-se neste trabalho pelos critérios alta elevação/curvatura convexa nas 4 direções de vertentes (norte, sul, leste e oeste), e baixa elevação/curvatura côncava também nas 4 direções de vertentes, como mostra a tabela abaixo. A faixa intermediária de elevação não foi usada por ser considerada irrelevante, já que pode ser interpolada a partir dos dados dos extremos, sem a necessidade de medição direta.

Tabela 4 - Critérios para alocação dos tensiômetros.

\begin{tabular}{l|l|l|c}
\hline Atributo & Critério & Valor & Decisão \\
\hline \multirow{4}{*}{ Elevação } & Alta & $>=180 \mathrm{~m}$ & 1 \\
\cline { 2 - 4 } & Intermediária & $116 \mathrm{~m}<\mathrm{elev}<180 \mathrm{~m}$ & 0 \\
\cline { 2 - 4 } & Baixa & $<=116 \mathrm{~m}$ & 1 \\
\hline \multirow{4}{*}{ Declividade } & Alta & $>=30^{\circ}$ & 0 \\
\cline { 2 - 4 } & Intermediária & $10^{\circ}<$ decliv $<30^{\circ}$ & 0 \\
\cline { 2 - 4 } & Baixa & $<=10^{\circ}$ & 1 \\
\hline \multirow{4}{*}{ Orientação } & Norte & $355-5^{\circ}$ & 1 \\
\cline { 2 - 4 } & Sul & $175-185^{\circ}$ & 1 \\
\cline { 2 - 4 } & Leste & $85-95^{\circ}$ & 1 \\
\cline { 2 - 4 } & Oeste & $265-275^{\circ}$ & 1 \\
\hline \multirow{2}{*}{ Curvatura } & Côncava & $<0^{\circ} / \mathrm{m}$ & $>0 \% / \mathrm{m}$ \\
\cline { 2 - 4 } & Convexa & $>0$ & 1 \\
\hline
\end{tabular}


Piezômetro: Esse equipamento monitora o nível do lençol freático, consequentemente, sua recarga ou esgotamento. O nível freático recebe influência da elevação do terreno, tendendo a segui-lo. Logo, optou-se pelos critérios alta/baixa elevação na alocação do piezômetro, conforme a tabela abaixo. Foi desconsiderada a faixa intermediária de elevação pelo fato de poder ser interpolada a partir dos dados dos extremos.

Tabela 5 - Critérios para alocação dos piezômetros.

\begin{tabular}{l|l|l|c}
\hline \multirow{2}{*}{ Atributo } & Critério & Valor & Decisão \\
\hline \multirow{4}{*}{ Elevação } & Alta & $>=180 \mathrm{~m}$ & 1 \\
\cline { 2 - 4 } & Intermediária & $116 \mathrm{~m}<$ elev $<180 \mathrm{~m}$ & 0 \\
\cline { 2 - 4 } & Baixa & $<=116 \mathrm{~m}$ & 1 \\
\hline \multirow{5}{*}{ Orientação } & Alta & $>=30^{\circ}$ & 0 \\
\cline { 2 - 4 } & Intermediária & $10^{\circ}<$ decliv $<30^{\circ}$ & 0 \\
\cline { 2 - 4 } & Baixa & $<=10^{\circ}$ & 0 \\
\hline \multirow{2}{*}{ Curvatura } & Norte & $355-5^{\circ}$ & 0 \\
\cline { 2 - 4 } & Sul & $175-185^{\circ}$ & 0 \\
\cline { 2 - 4 } & Leste & $85-95^{\circ}$ & 0 \\
\cline { 2 - 4 } & Oeste & $265-275^{\circ}$ & 0 \\
\hline
\end{tabular}

Definidos os critérios, o próximo passo foi extrair os planos de informação para cada um desses critérios, auxiliado pela ferramenta calculadora raster do ArcMAP $^{\circledR}$, conforme os valores numéricos de cada um.

\section{Cruzamento dos Planos de Informação}

Os planos de informações de cada critério foram cruzados usando o comando " $\mathrm{E}$ boolenano" do conjunto de ferramentas de análise espacial do ArcMAP, com a finalidade de se chegar a mapas de alocação para cada instrumento.

Estação fluviométrica: foram cruzados os 3 planos de informação gerados: elevação baixa, declividade alta e curvatura convexa;

Estação meteorológica: foram cruzados os 8 planos de informação gerados: elevação alta/intermediária/baixa, declividade baixa e orientação norte/sul/leste/oeste, da seguinte forma:

\section{Grupo 1}

1) Elevação alta, declividade baixa, orientação norte;

2) Elevação alta, declividade baixa, orientação leste;

3) Elevação alta, declividade baixa, orientação sul;

4) Elevação alta, declividade baixa, orientação oeste.

Grupo 2

1) Elevação baixa, declividade baixa, orientação norte;
2) Elevação baixa, declividade baixa, orientação leste;

3) Elevação baixa, declividade baixa, orientação sul;

4) Elevação baixa, declividade baixa, orientação oeste.

Grupo 3

1) Elevação intermediária, declividade baixa, orientação norte;

2) Elevação intermediária, declividade baixa, orientação leste;

3) Elevação intermediária, declividade baixa, orientação sul;

4) Elevação intermediária, declividade baixa, orientação oeste.

Tensiômetro: foram cruzados os 6 planos de informação gerados: elevação alta/baixa, curvatura côncava/convexa e orientação norte/sul/leste/oeste, com a seguinte disposição apresentada abaixo:

Grupo 1
1) Elevação alta, curvatura convexa, orientação norte;
2) Elevação alta, curvatura convexa, orientação leste;
3) Elevação alta, curvatura convexa, orientação sul;
4) Elevação alta, curvatura convexa, orientação oeste.

Grupo 2

1) Elevação baixa, curvatura côncava, orientação norte; 
2) Elevação baixa, curvatura côncava, Piezômetro: não houve cruzamento para esse orientação leste; instrumento porque os dois critérios usados

3) Elevação baixa, curvatura côncava, (elevação alta/baixa) fazem parte do mesmo orientação sul;

4) Elevação baixa, curvatura côncava, orientação oeste. atributo (elevação). Logo, o mapa de alocação foram dois planos de informações, um contendo as áreas de elevação alta e o outro de baixa.

\section{RESULTADOS E DISCUSSÕES}

\section{Levantamento Geodésico}

O levantamento geodésico tornou o processo de obtenção de dados altimétricos mais rápido, simples e confiável.

Nas áreas irregulares do terreno, isto é, com curvas, valas, ondulações etc., se rastreavam mais pontos para caracterizar melhor a superfície, enquanto que nas áreas regulares (mais planas), se rastreavam menos pontos. Isso porque a modelagem do terreno depende da quantidade e qualidade dos pontos levantados para que seja o mais fiel possível à realidade. A figura 5 traz a distribuição dos pontos, onde se percebe que as vertentes dos canais de drenagem e topos dos morros, por serem mais irregulares, tiveram maior densidade de pontos. Ao todo, foram 3573 pontos rastreados, com densidade de 12,72 pontos por hectare.

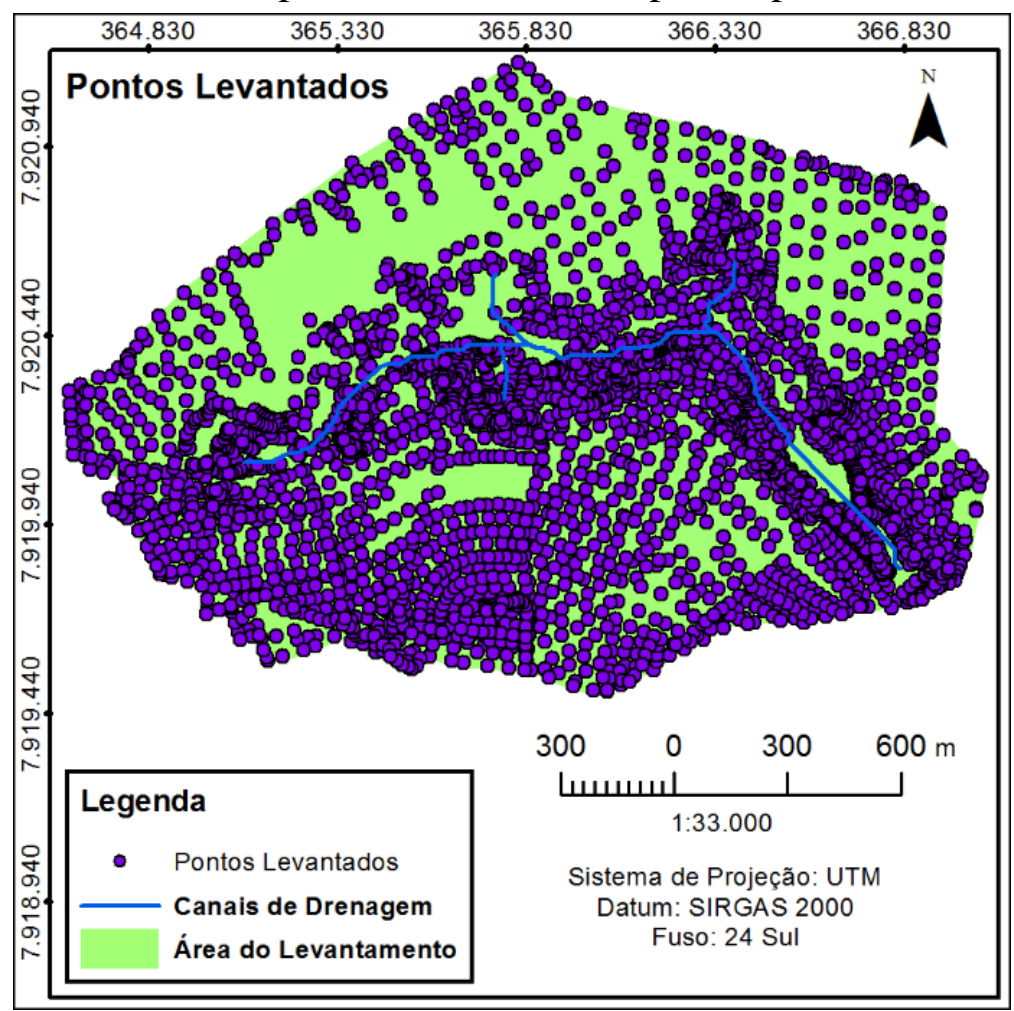

Figura 5 - Mapa de distribuição dos pontos levantados.

\section{Pós-processamento e Geração do MDE}

Ao final do pós-processamento dos pontos rovers no GNSS Solutions ${ }^{\circledR}$ tinham-se 3668 pontos pós-processados, diferente dos 3573 pontos obtidos do levantamento e usados como entrada no processamento. Esse fato trouxe problemas, pois, ao avaliar o MDE gerado, percebeu-se que haviam algumas falhas como pontos duplicados ou extremamente próximos entre si, ou células com valores de cota discordantes em relação às células vizinhas. Após a exclusão desses pontos, um novo MDE foi gerado pelo método de interpolação top to raster (Figura 6).

\section{Geração dos MNTs}

A partir do MDE, a bacia foi delimitada e foram gerados os MNTs de elevação, declividade, orientação de vertentes e curvatura. As figuras 7 a 11 apresentam os esses resultados a seguir.

Delimitação da Bacia: Para a delimitação, foi necessário determinar o ponto do exutório, que é o local onde o córrego recebe um afluente. A área da bacia delimitada mediu 248,16 ha e o perímetro $7,06 \mathrm{~km}$. A figura 7 traz essa delimitação. 


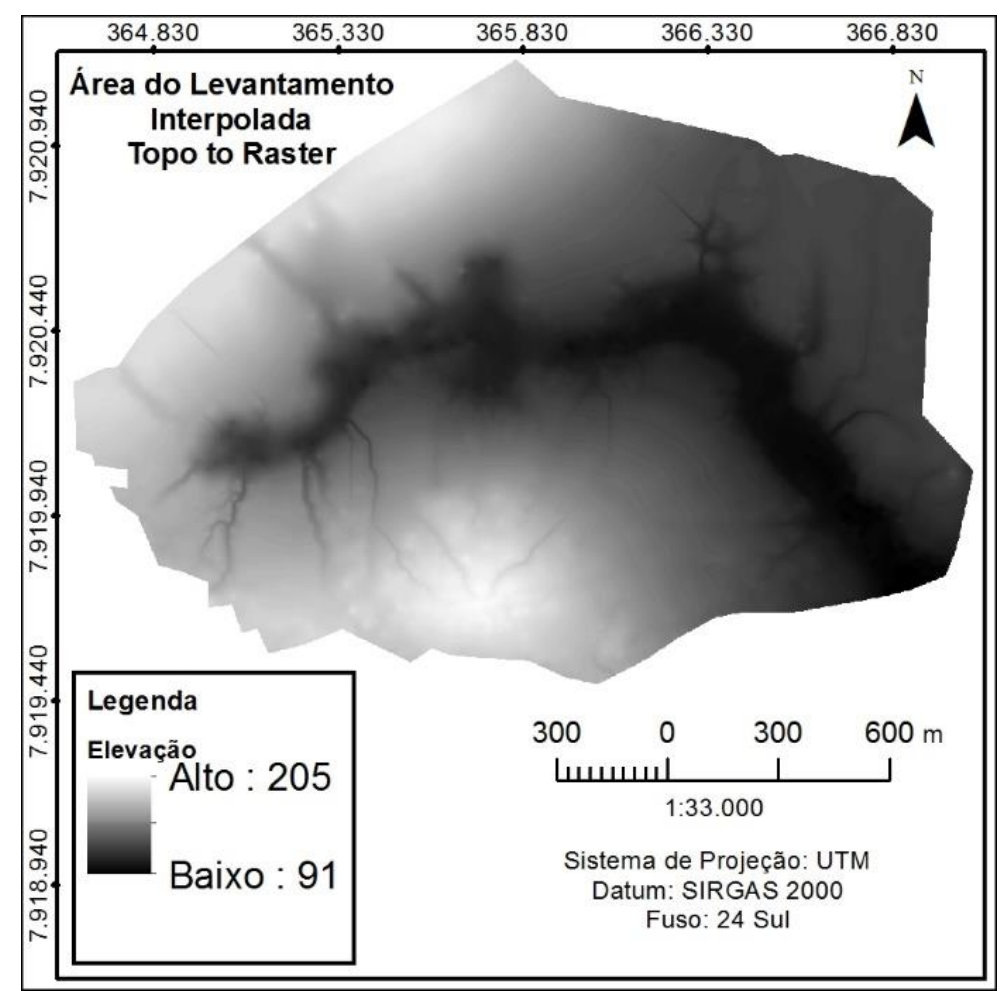

Figura 6 - Interpolação da área de estudo pelo método top to raster.

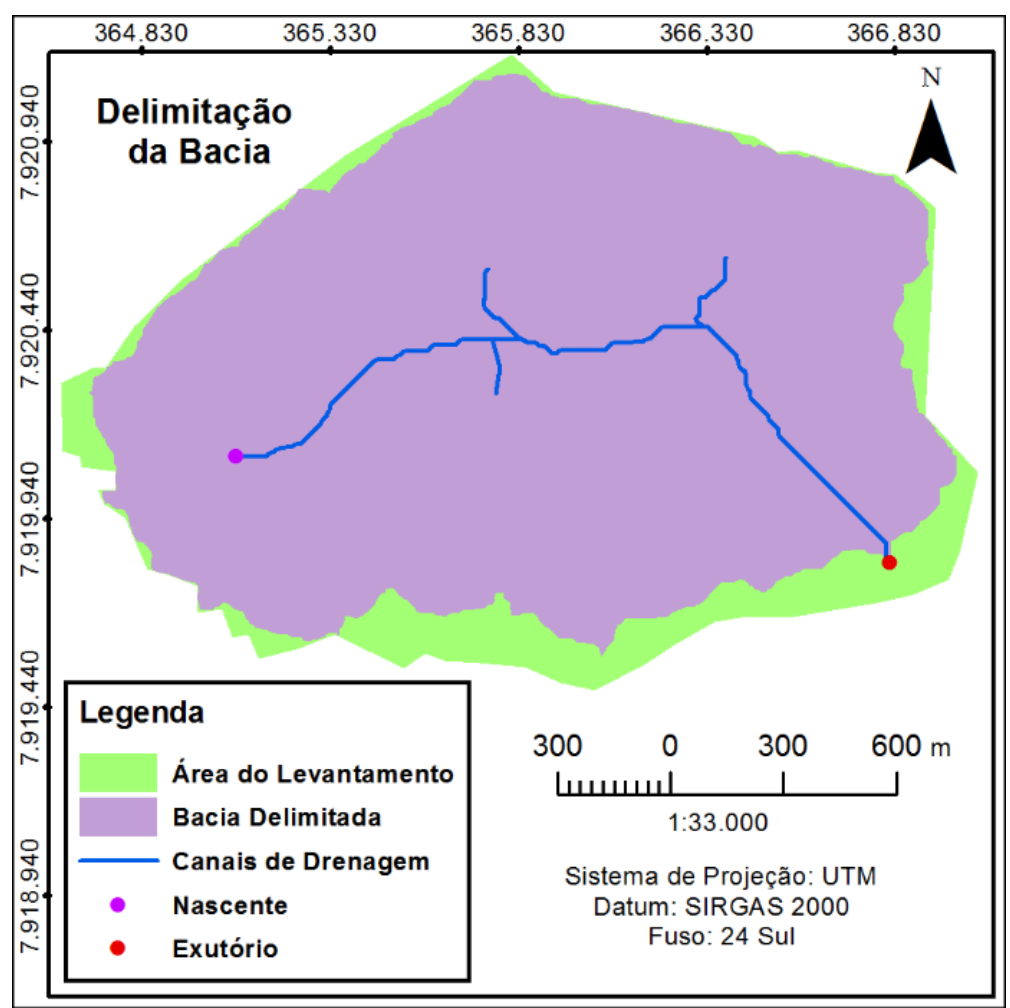

Figura 7 - Delimitação da Bacia.

Elevação da Bacia: O mapa de elevação na figura 8 mostra que há uma amplitude de $114 \mathrm{~m}$ entre a cota mais alta (205 $\mathrm{m})$ e a mais baixa ( 91 m). É possível perceber também que as maiores elevações estão na parte oeste da bacia e que há uma transição drástica no alargamento do vale do córrego no sentido da nascente para o exutório (oeste para leste).
Declividade da Bacia: O mapa da declividade representada na figura 9 mostra maiores inclinações a oeste da bacia, ou seja, na região da nascente, podendo ser percebido pela variação da cor verde-claro para vermelho. Comparando com o mapa de elevação, percebe-se sintonia com o alargamento do vale na direção à jusante, onde as declividades são menores. 


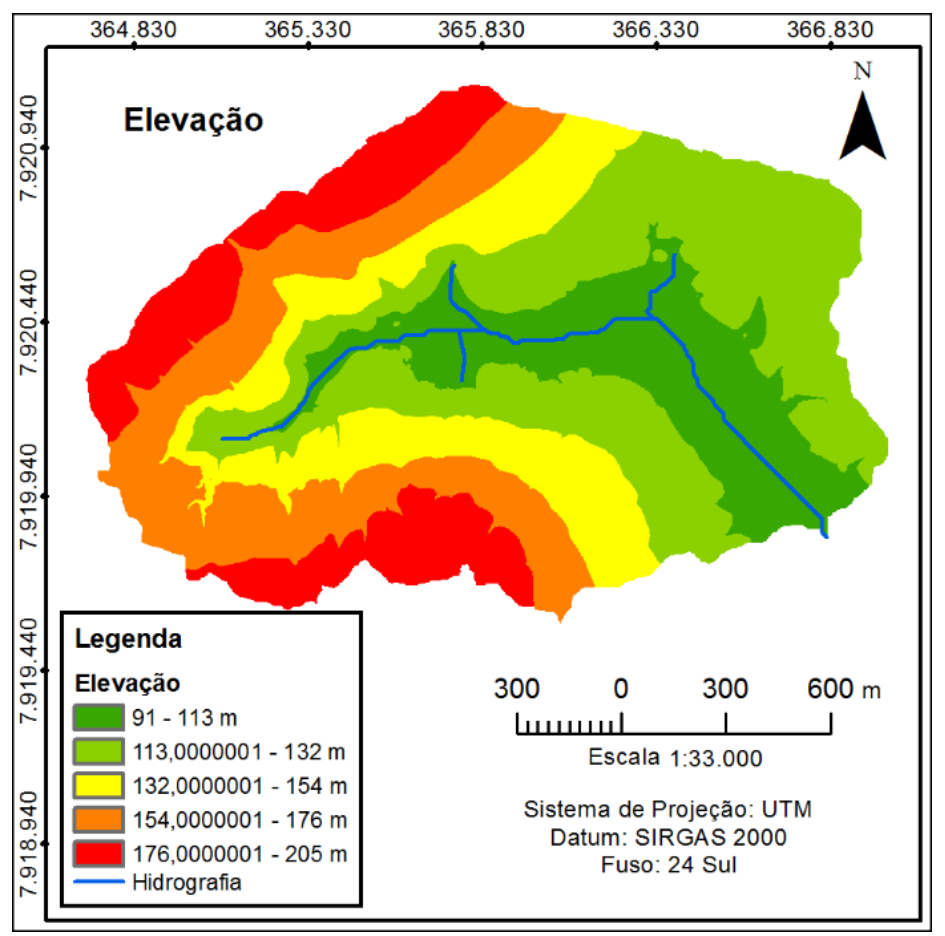

Figura 8 - Elevações da Bacia.

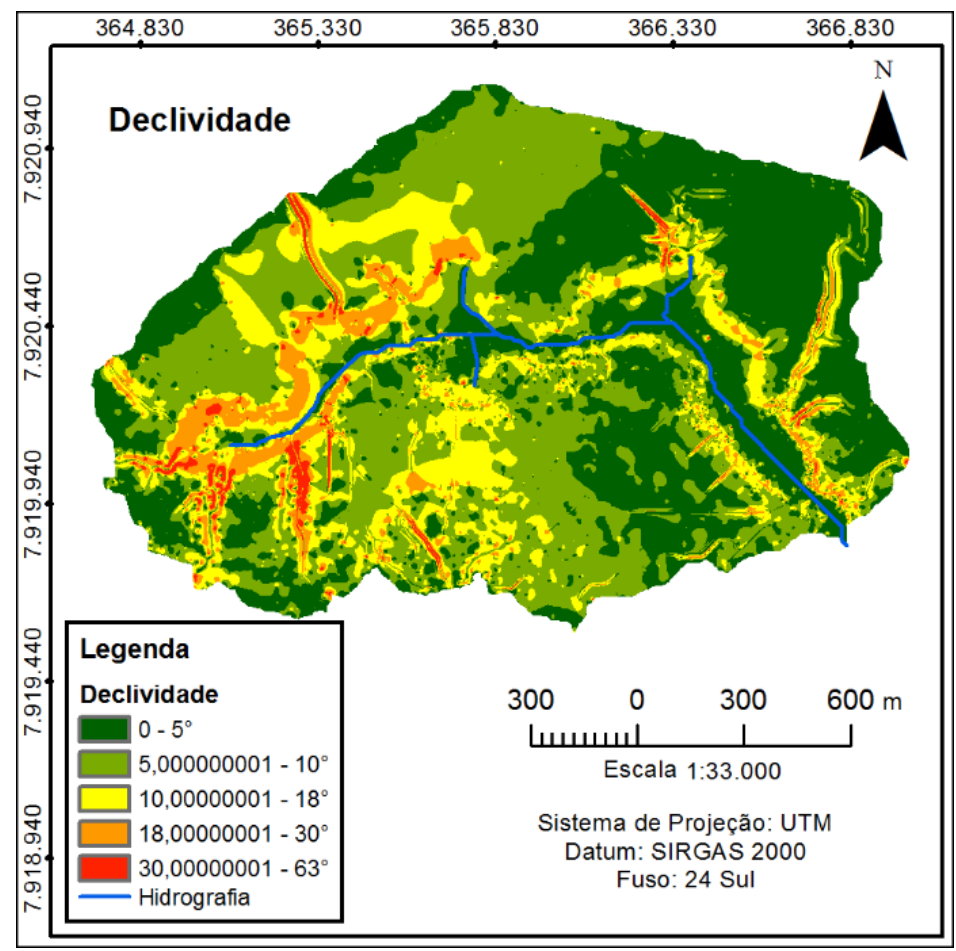

Figura 9 - Declividades da Bacia.

Orientação das Vertentes: A figura 10 traz o mapa de orientação das vertentes da bacia, onde cada orientação (norte, sul, leste e oeste) compreendeu um arco de $90^{\circ}$, sendo o ângulo central de cada arco a direção exata de cada orientação. Por exemplo, a orientação leste compreendeu o arco de $45^{\circ}$ a $135^{\circ}$, sendo $90^{\circ}$ o ângulo central desse arco que é o ângulo da direção leste (no $\operatorname{ArcMAP}^{\circledR}, 0^{\circ}$ equivale à direção norte e a contagem dos ângulos se dá no sentido horário). Por essa representação percebeu-se que as vertentes da bacia estão na maioria orientadas para norte, sul e leste, enquanto que há pouca voltada para oeste.

Curvatura: O MNT da figura 11 traz as curvaturas do terreno, podendo ser côncavas ou convexas. O comando curvatura define que superfícies côncavas são aquelas cuja razão declividade por unidade de distância é menor que $0 \% \mathrm{~m}$ (valores negativos), enquanto que as 
superfícies convexas possuem razão maior que $0 \% \mathrm{~m}$ (valores positivos). Pelo mapa acima, percebe-se claramente que as regiões côncavas se situam no leito do vale do córrego, o que era de se esperar, enquanto que as vertentes são predominantemente convexas.

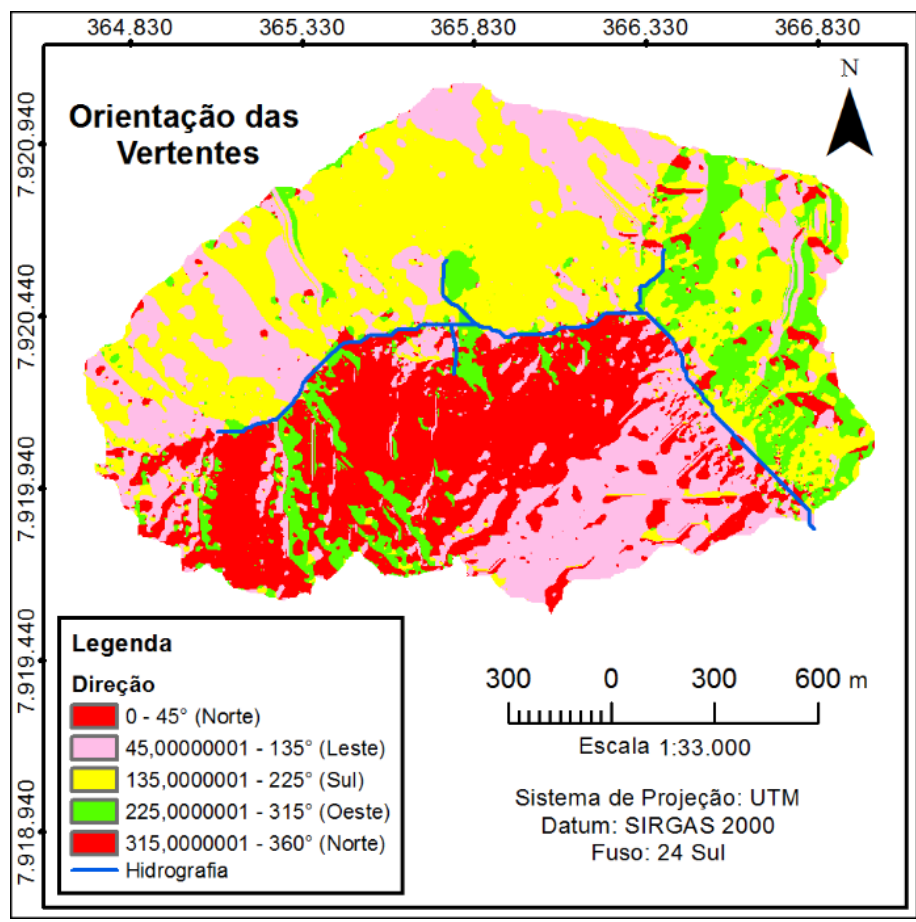

Figura 10 - Orientações das vertentes da Bacia.

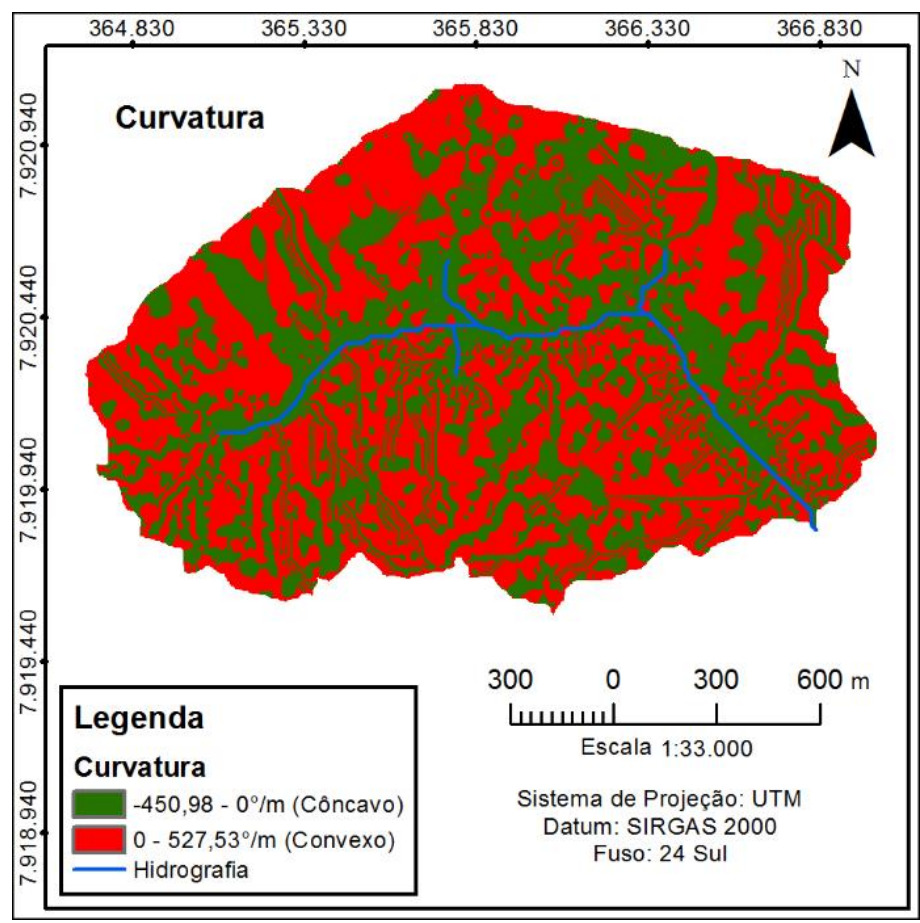

Figura 11 - Curvatura.

\section{Determinação das áreas de Alocações}

Depois de gerado os MNTs, foram extraídos deles os planos de informação para cada critério de alocação dos instrumentos, que após serem cruzados, chegou-se aos resultados com as áreas propícias à instalação de cada instrumento, conforme apresentado nas figuras 12 a 18 a seguir.
Estação Fluviométrica: Esperava-se para essa alocação que o vale ao longo do canal apresentasse algum trecho cuja seção transversal fosse de alta declividade e curvatura convexa, mas o mapa acima mostra que isso não foi encontrado nem no exutório, onde obrigatoriamente deve ser instalada uma estação fluviométrica, nem acima. 


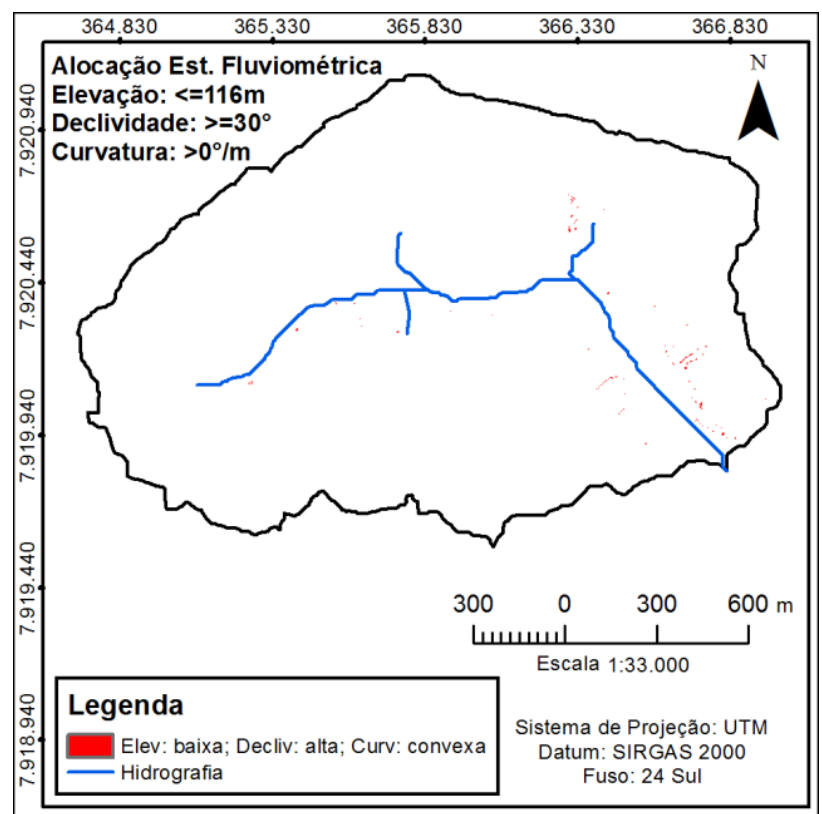

Figura 12 - Áreas propícias à alocação da estação fluviométrica.

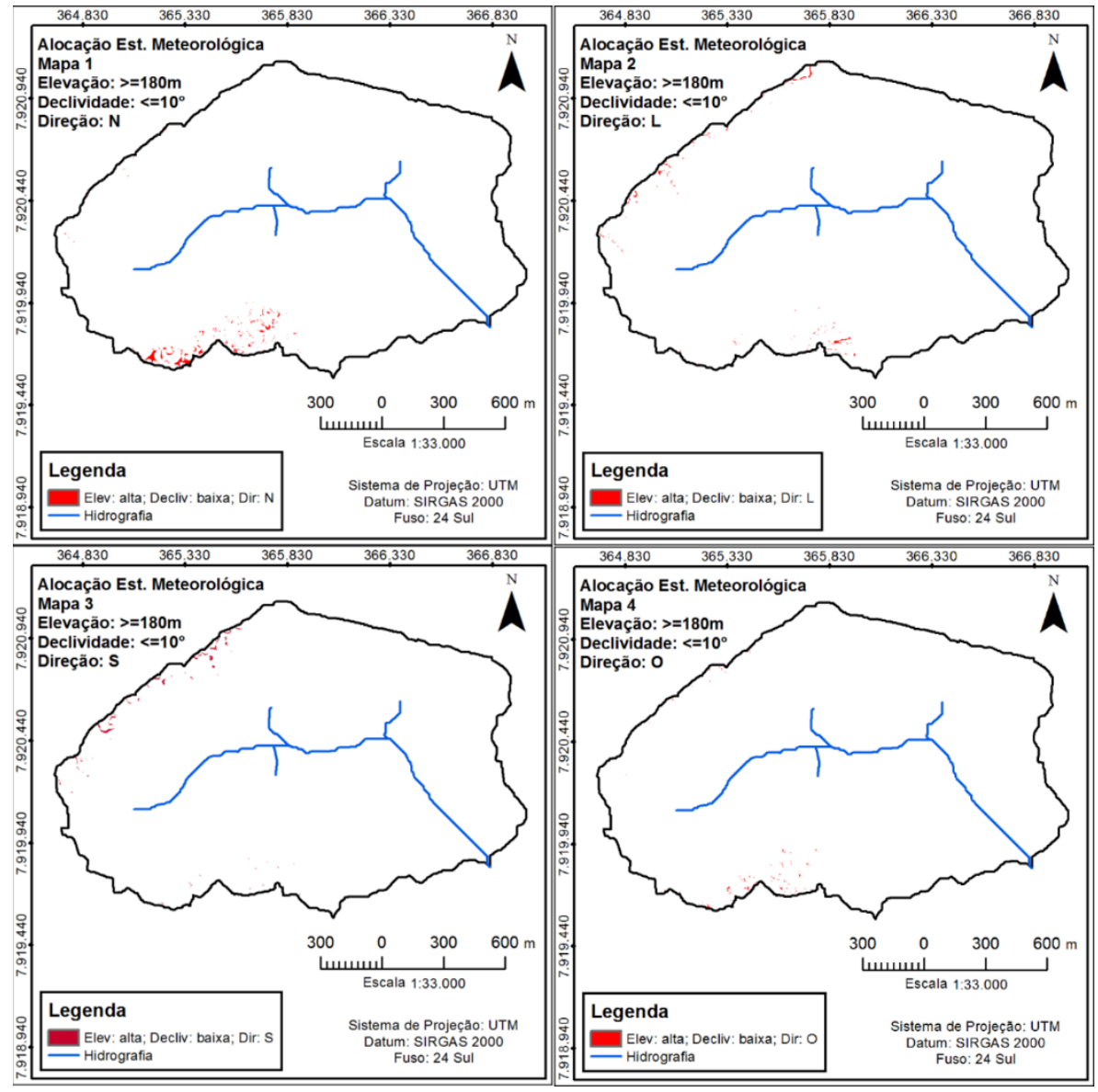

Figura 13 - Áreas propícias à alocação das estações meteorológicas, grupo 1. As áreas em hectares propícias à instalação foram: Mapa 1: 0,74; Mapa 2: 0,44; Mapa 3: 0,42; Mapa 4: 0,17.

Estação Meteorológica: Para esse instrumento, os cruzamentos se deram em 3 grupos.

O resultado foi 12 mapas de alocação conforme as figuras 13 a 15 .

Tensiômetro: Para esse instrumento, os cruzamentos se deram em 2 grupos.
O resultado foi 8 mapas de alocação, conforme apresentado nas figuras 16 e 17.

Piezômetro: As áreas em hectares propícias à instalação foram:

Mapa 1: 31,86; Mapa 2: 51,36, conforme ilustra a figura 18 . 


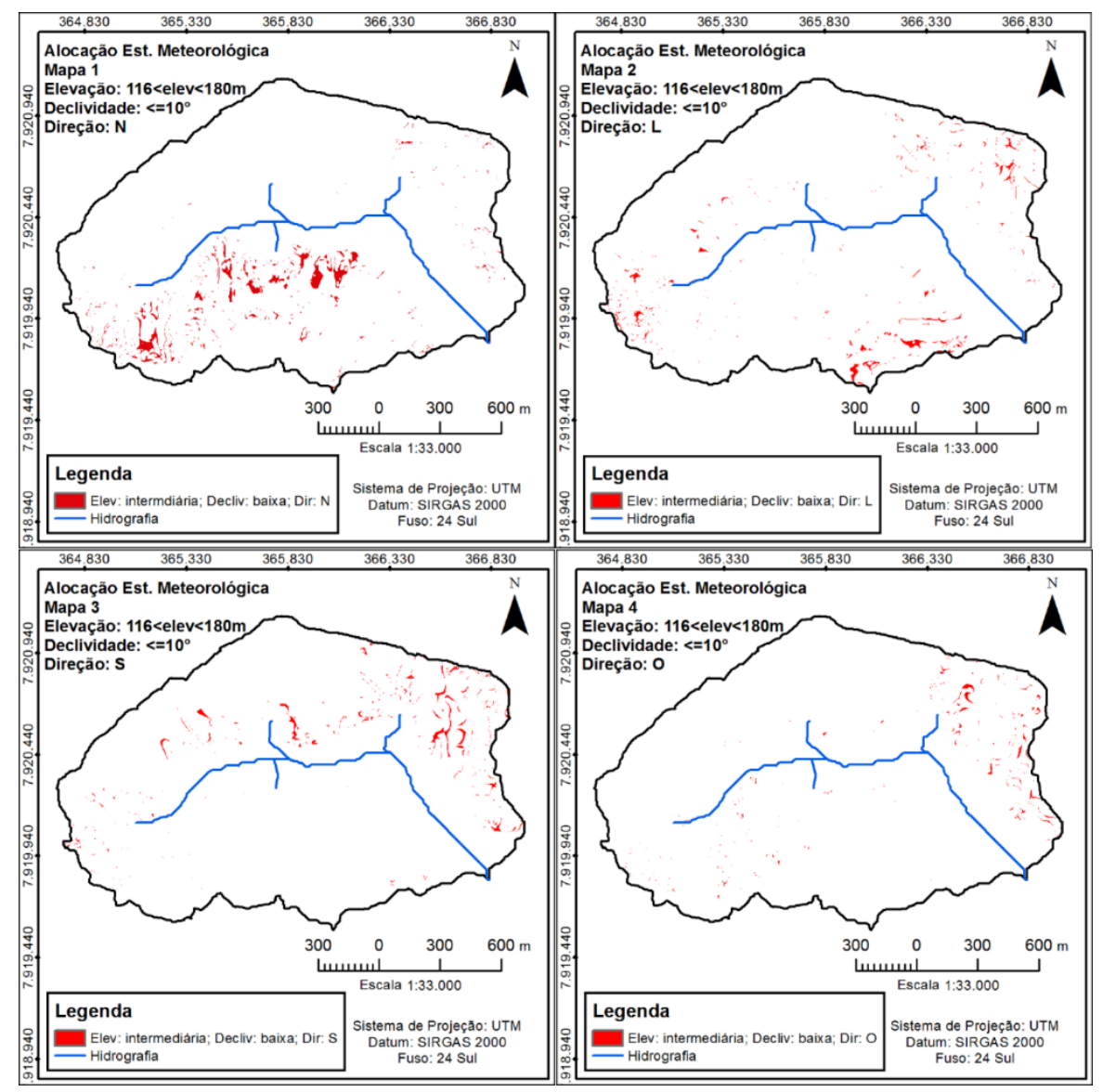

Figura 14 - Áreas propícias à alocação das estações meteorológicas, grupo 2. As áreas em hectares propícias à instalação, foram: Mapa 1: 0,88; Mapa 2: 0,87; Mapa 3: 0,99; Mapa 4: 0,57.

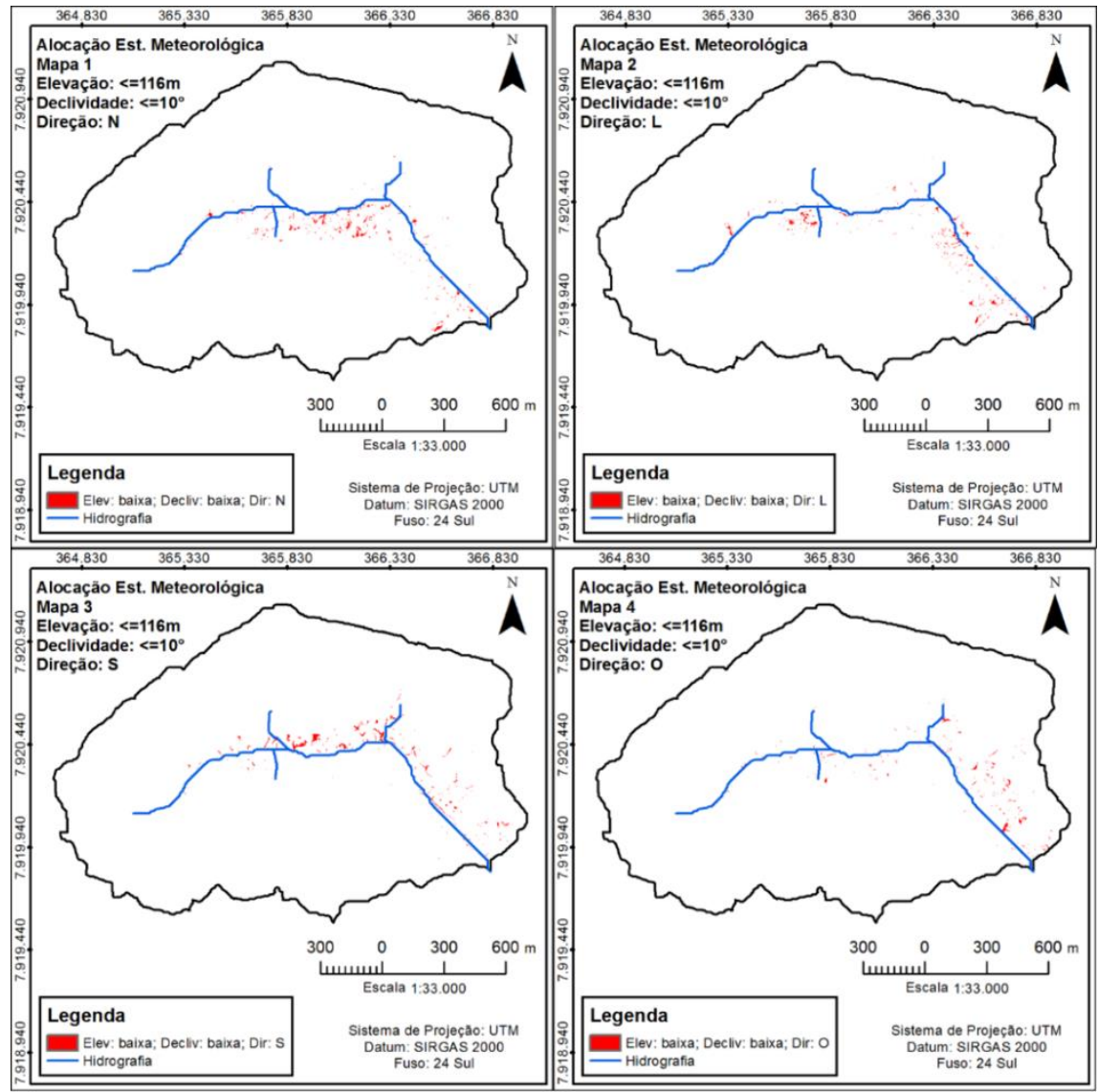

Figura 15 - Áreas propícias à alocação das estações meteorológicas, grupo 3. As áreas em hectares propícias à instalação, foram: Mapa 1: 4,47; Mapa 2: 2,43; Mapa 3: 2,28; Mapa 4: 1,11. 


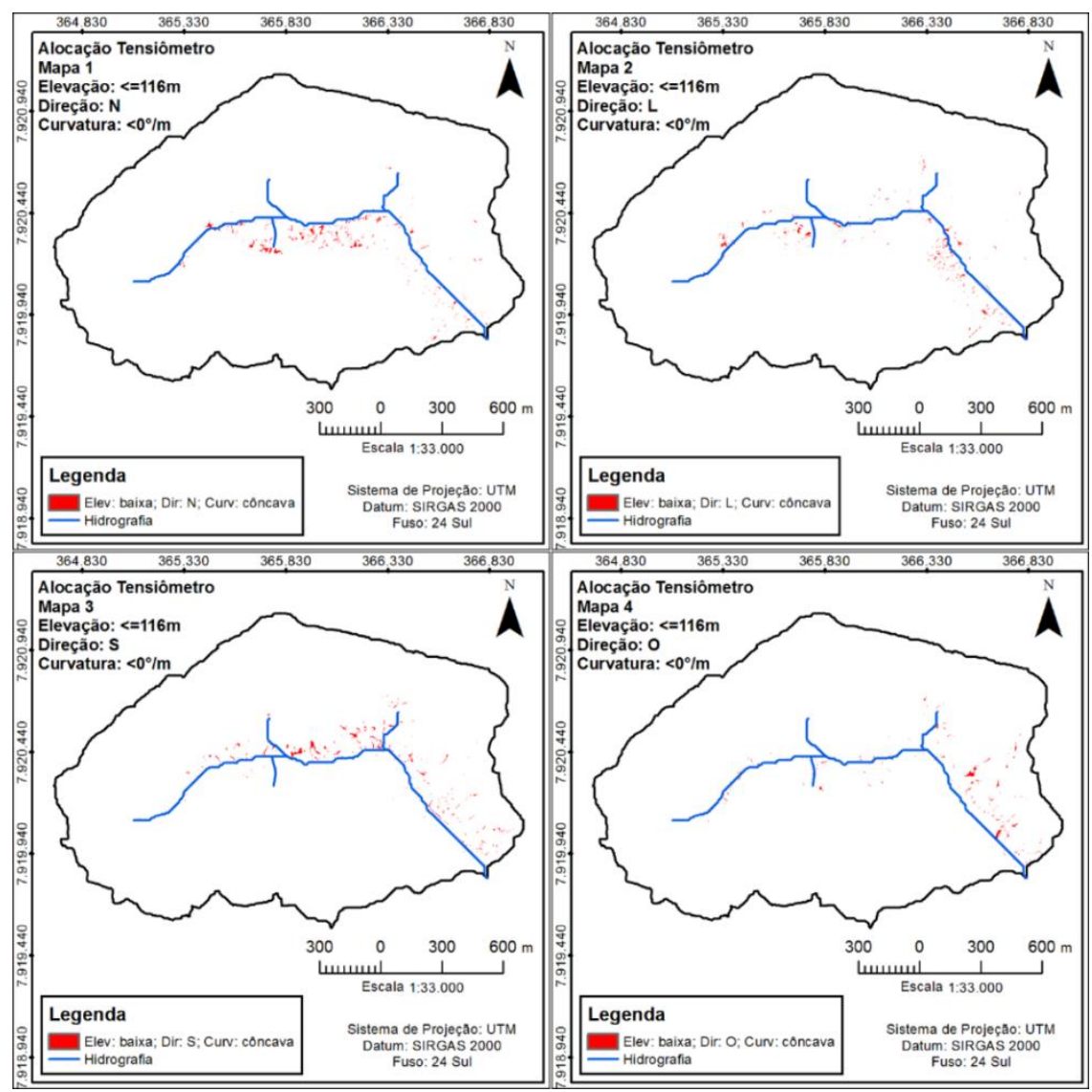

Figura 16 - Áreas propícias à alocação dos tensiômetros, grupo 1. As áreas em hectares propícias à instalação, foram: Mapa 1: 0,6; Mapa 2: 0,46; Mapa 3: 0,39; Mapa 4: 0,21.

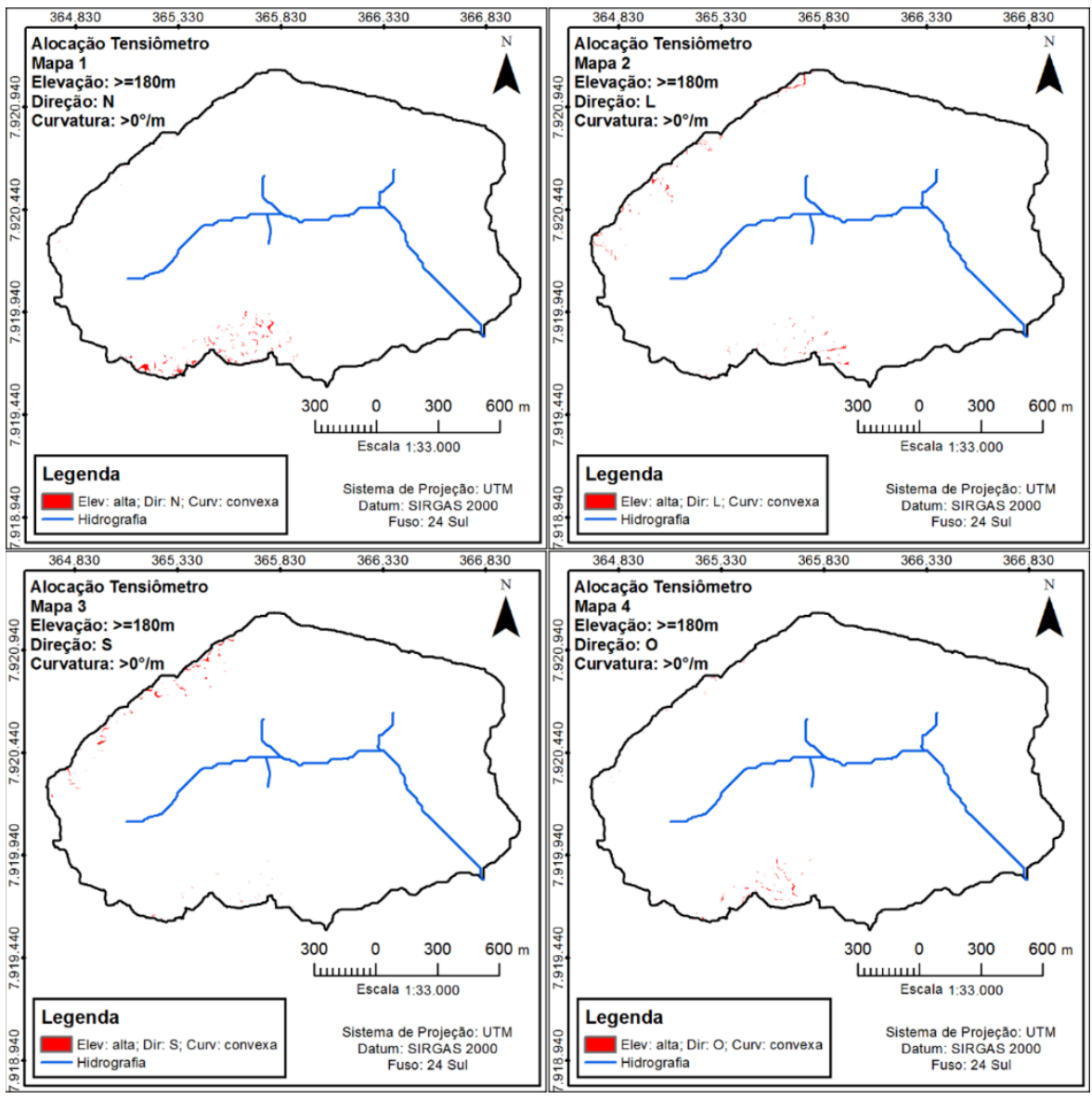

Figura 17 - Áreas propícias à alocação dos tensiômetros, grupo 2. As áreas em hectares propícias à instalação foram: Mapa 1: 0,9; Mapa 2: 0,75; Mapa 3: 0,92; Mapa 4: 0,58. 

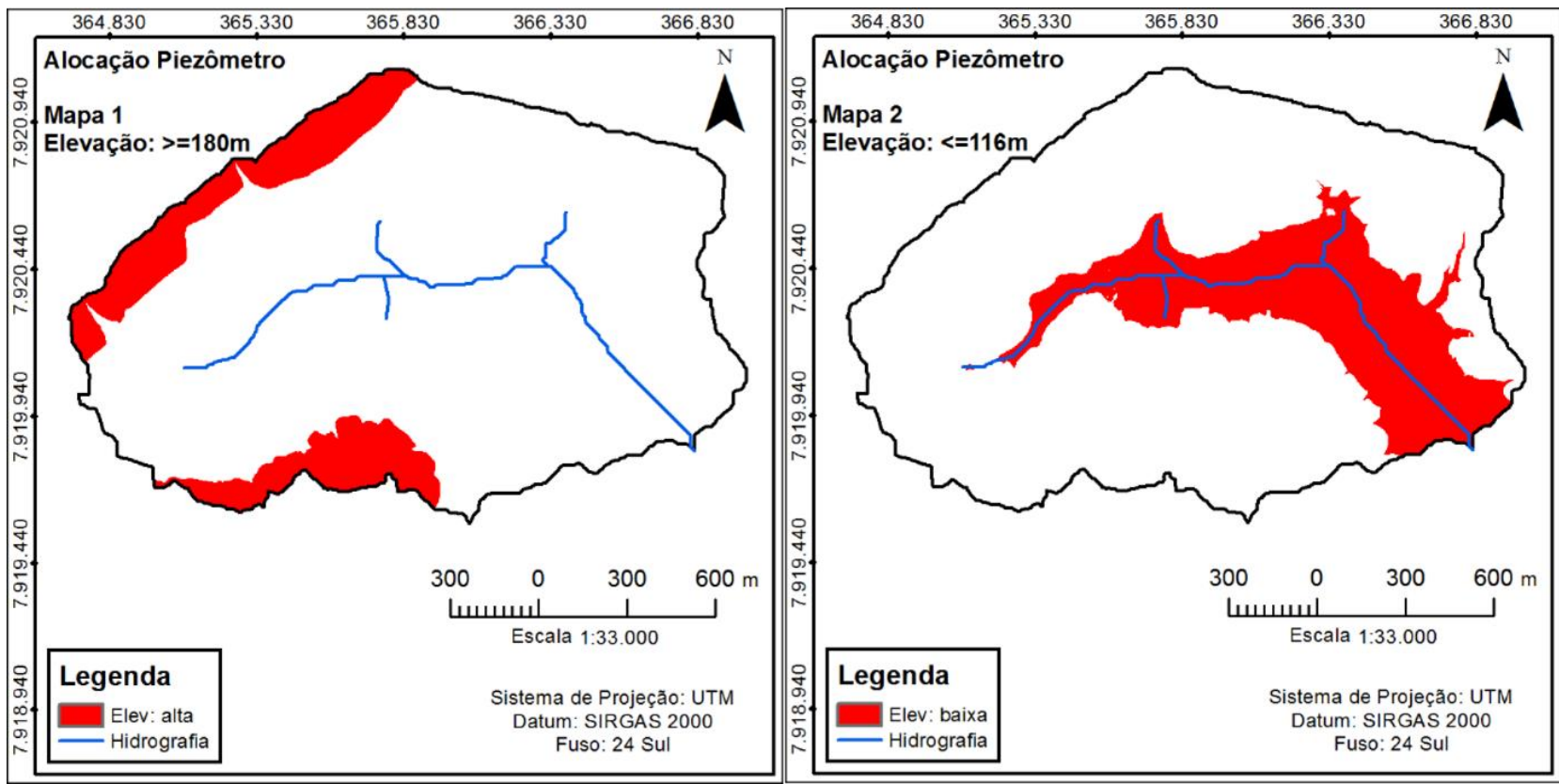

Figura 18 - Áreas propícias à alocação dos piezômetros.

\section{CONSIDERAÇÕES FINAIS}

O uso de SIG para a alocação de instrumentos se mostrou satisfatório, pois a metodologia baseada na geração do MDE, delimitação supervisionada da bacia, geração dos MNTs e o cruzamento dos planos de informação permitiu automatizar o processo de alocação. Também se conclui que o uso de SIG tornou o processo de alocação objetivo, o que permite agilidade e mais acurácia no processo decisório de instrumentação de bacias.

\section{AGRADECIMENTOS}

Os autores externam seus agradecimentos ao Instituto Federal do Espírito Santo, por ter cedido os materiais para a realização deste trabalho.

\section{REFERÊNCIAS}

ASSAD, E.D.; SANO, E.E.; MEIRELLES, M.L.; MOREIRA, L Estruturação de dados geoambientais no contexto de microbacia hidrográfica. In: ASSAD, E.D. \& SANO, E.E. (Orgs). Sistema de informações geográficas: aplicações na agricultura. 2. ed. rev. e ampl. Brasília: EMBRAPASPI/EMBRAPA-CPAC, 1998, p. 119-137.

BARROS, P.P.S.; FARIA, V.G.; CASSIANO, C.C.; MAIA, C.B.; STRABELI, T; FORTE, Y.A.; BOSQUILIA, R.W.D. Avaliação de atributos topográficos extraídos a partir de modelos numéricos do terreno com diferentes resoluções. In: SIMPÓSIO BRASILEIRO DE SENSORIAMENTO REMOTO, 17, 2015, João Pessoa. Anais...João Pessoa: INPE, 2015, p. 4713-4720.

BRASIL. Lei $n^{\circ}$ 9.433, de 08 de janeiro de 1997. Disp. em: http://www.planalto.gov.br/ccivil_03/leis/L9433.htm.

Acessado em: 10nov2016.

BRASIL. Decreto $n^{\circ}$ 94.076, de 05 de março de 1987. Disp. em: http://www2.camara.leg.br/legin/fed/decret/1980-

1987/decreto-94076-5-marco-1987-444426-

publicacaooriginal-1-pe.html. Acessado em: 10nov2016.

CECÍLIO, R.A.; COUTINHO, L.M.; XAVIER, A.C.; MOREIRA, M.C.; ZANETTI, S.S.; GARCIA, G.O. Delimitação de bacia hidrográfica em região montanhosa a partir de diferentes modelos digitais de elevação. Seminário Ciências Agrárias... Londrina, v. 34, n. 5, p. 2007-2024, 2013. ESPÍRITO SANTO. Instituto Jones dos Santos Neves. Mapas precipitação média anual acumulada e temperatura média anual registrada no Estado do Espírito Santo, 1977-2006. Vitória: IJSN, 2011. 2 mapas. Escala 1:1.724.138. Disp. em: www.ijsn.es.gov.br/mapas/. Acessado em: 16out2016.

ENVIRONMENTAL SYSTEMS RESEARCH INSTITUTE, INC. (ESRI). Software ArcGIS ${ }^{\circledR}$, versão 10.5, Califórnia (EUA), 2016.

GUEDES, H.A.S.; CAPOBIANGO, G.V.; MARTINS, V.S.; SILVA, D.D.. Análise da precisão entre os métodos de interpolação Krigagem Ordinária e Topo to Raster na geração de modelos digitais de elevação. In: SIMPÓSIO BRASILEIRO DE SENSORIAMENTO REMOTO, 15, 2011, Curitiba. Anais...Curitiba: INPE, 2011, p. 4239-4246.

INSTITUTO BRASILEIRO DE GEOGRAFIA E ESTATÍSTICA (IBGE). Aplicativo on-line IBGE-PPP, versão: CSRS-PPP 1.05/34613, Rio de Janeiro, 2016. Disp. em: http://www.ppp.ibge.gov.br/ppp.htm.

MARQUES, H.G.; PENATTI, N.C.; PARANHOS FILHO, A.C.; FROEHLICH, O.; ALMEIDA, T.I.R.; SHIMABUKURO, Y. Comparação entre os modelos de elevação SRTM, TOPODATA e ASTER na delimitação automática de rede de drenagem e limite de bacia hidrográfica. In: SIMPÓSIO BRASILEIRO DE SENSORIAMENTO REMOTO, 15, 2011, Curitiba. Anais...Curitiba: INPE, 2011, p. $1271-1278$.

MOTA, A.A.; GIGLIO, J.N.; KOBIYAMA, M. Instalação de uma pequena bacia experimental florestal: estudo de caso da bacia do Rio Araponga. Revista Engenharia Sanitária e Ambiental. Rio de Janeiro, 27 out. 2016. Disp. em: http://www.scielo.br/pdf/esa/2016nahead/1809-4457-esaS1413_41522016154610.pdf. Acessado em: 01dez2016.

NASCIMENTO, E.R.; REIS NETO, J.M.; REBELO, A.M.A.; 
SAMPAIO, T.V.M.; SILVEIRA, C.T. Parâmetros geomorfométricos do relevo no entendimento do nível de exposição dos sistemas cársticos... Revista Brasileira de Geociências. São Paulo, v. 42, n.1, p. 81-90, 2012.

NOVO, E.M.L.M. Ambientes fluviais. In: FLORENZANO, T.G. (Orga). Geomorfologia: conceitos e tecnologias atuais. São Paulo: Oficina de Textos, 2008, p. 219-246.

PANOSO, L.A;. GOMES, I.A.; PIRES FILHO, A.M.; BONELLI, S. Levantamento de reconhecimento dos solos do Estado do Espírito Santo. Boletim técnico n. 45. Rio de Janeiro: Embrapa/SNLCS, 1978.

PASSARELLA, S.; LADEIRA, F.S.B.; LIESENBERG, V. Morfometria da bacia do Rio São João, MG: uma proposta de entendimento dos limites e da dinâmica das superfícies erosivas. Revista Brasileira de Geomorfologia. v.17, n. 2, p. 241-252, 2016.

SANTOS, S.L.M.; JUSTINA, E.E.D.; FERREIRA, M.M. Mapeamento geomorfológico da Bacia do Igarapé Belmont Porto Velho - Rondônia. Revista Brasileira de Geomorfologia. v. 13, n. 3, p. 255-266, 2012.
SCHLOSSER, R.T. Diferentes métodos de interpolação e a gestão dos recursos hídricos. In: CONGRESSO INTERNACIONAL DE TECNOLOGIAS PARA O MEIO AMBIENTE, 3, 2012, Bento Gonçalves. Anais...Bento Gonçalves: ISAM/PROAMB, 2012.

VALENTE, O.F. Produtor rural é fundamental na conservação dos recursos hídricos. Entrevista concedida à Revista Informe Agropecuário da EPAMIG, Belo Horizonte, v. 32, n. 263, 2011.

VARGAS, T.D.; GOMES, M.A.; LANI, J.L.; PIMENTA, D.F.N.; NOGUEIRA, R.S.; SOUZA, R.M Sistema de Informações Geográficas como ferramenta para o manejo de bacias hidrográficas. Informe Agropecuário. Belo Horizonte, v. 32, n. 263, p. 12-20, 2011.

Submetido em 13 de outubro de 2017 Aceito em 27 de junho de 2018 